\title{
ANNOUNCEMENTS
}

\section{JUY Matire}

July 5-9. 4th Annual Meeting on Oncogenes. Frederick, MD. Info: Margaret Fanning, Conference Coordinator, PRI NCI-Frederick Cancer Research Facility, Frederick, MD 21701-1013

July 6-8. 21 st Century Prospects for Biotechnology in Agriculture and the Environment (immediately preceding the meeting of the International Union for Biochemistry). Prague, Czechoslovakia. Info: Karel Zeleny, Agrogen, JZD Slusovice, CS-753 15, Cizechoslovakia, or Ronald E. Cape, Chairman, Cetus Corp., 1400 Fifty-Third St., Emeryville, CA 94608

July 17-22. 8th International Biotechnology Symposium. Paris. Info: Secretariat, VIIIe Symposium de Biotechnologie, 14 rue Mandar, 75002 Paris, France

July 18-21. Interphex USA. New York, NY. Info: Cahners Exposition Group, Cahners Plaza, 1350 E. Touhy Ave., P.O Box 5060, Des Plains, IL 60017-5060

July 25-29. Western Forest Genetics Association Scientific/Technical Meeting Davis, CA. Info: Robert D. Westfall, Chairman, Local Arrangements, RRO \# I Box 1171, Davis, CA 95616

July 27-29. 7th Summer Symposium in Molecular Biology-Viruses, Pathogens, and Model Systems. University Park, PA. Info: Dee Reeves, Symposium Program Coordinator, 7th Summer Symposium in Molecular Biology, 208 South Frear Laboratory, The Pennsylvania State Univ., Unjversity Park, PA 16802

July 31-Aug. 4. Risk Assessment in Agricultural Biotechnology. Davis, CA. Info: Donna Hyatt, Dean's Office, College of A\&ES, Univ. of California, Davis, CA 95616

\section{AlPust Mastines}

Aug. 1-5. 8th International Conference on Cilobal Impacts of Applied Microbiology. Hong Kong. Info: S. T. Chang, Dept. of Biology, The Chinese University of Hong Kong, Shatin, New Territories, Hong Kong

Aug. 7-12. 1988 Annual Meeting of the Society for Industrial Microbiology. Chicago, IL. Info: Ann Kulback, SIM, P.O Box 12534, Arlington, VA 22209-8534

Aug. 7-13. 14th International Conference on Yeast Genetics and Molecular Biology. Espoo, Finland. Info: Tarja Koistinen, Research Laboratories, Alko Ltd, P.O. Box 250, SR 00101, Helsinki 10, Finland

Aug. 8-12. Biocatalytic Synthesis of Organic Compounds. Saratoga Springs, NY. Info: Jemifer Gensler, GE-CRD, P.O. Box 8, Schenectady, NY 12301

Aug. 9-11. North American Tannin Conference. Port Angeles, WA. Info: College of Forestry, Oregon State University, Corvallis, OR 97331

Aug. 11-13. International Symposium on Population Genetics and Germplasm Resources in Crop Improvement. Davis, CA. Info: See for July 31-Aug. 4.

Aug. 13-17. 2nd Symposium of the Protein Society. San Diego, CA. Info: Protein Symposium Secretariat, Suite 1015, 400 East Randolph, Chicago, IL 60601

Aug. 14-18. American Institute of Biological Sciences Annual Meeting. Davis, CA. Info: Louise Salmon, Meetings Manager, AIBS, 73011 th St., N.W., Washington, D.C. 20001

Aug. 14-19. 4th International Congress of Cell Biology. Montreal. Info: Congress Secretariat, 4th International Congress of Cell Bjology, National Research Council of Canada, Ottawa, Ontario, Canada K1A 0 R6

Aug. 20-27. 16th International Congress of Genetics. Toronto. Info: Congress Manager, 16th International Congress of Genetics, National Research Council of Canada, Ottawa, Ontario, Canada K1A OR6

Aug. 23-26. 7th International Symposium on Mass Spectrometry in Life Sciences. Ghent, Belgium. A. De Leenheer, Laboratoria voor Medische Biochemie en voor Klinische Analyse, Harelbekestraat 72, B9000 Ghent, Belgium

Aug. 24-28. Cold Spring Harbor Laboratory Conference on Mouse Molecular Genetics. Cold Spring Harbor, NY. Info: Meetings Coordinator, CSHL, Cold Spring Harbor, NY 11724

Aug. 29-Sept. 1. 102nd Annual International Meeting and Exposition of the Association of Official Analytical Chemists (includes "spotlight symposium" on biotechnology). Palm Beach, FL. Info: Administrative Manager, AOAC, $1111 \mathrm{~N}$. 19th St., Suite 210, Arlington, VA 22209

Aug. 31-Sept. 3. 4th Separation Science and Biotechnology Symposium. Gargnano del Garda, Italy. Info: Pier Giorgio Righetti, Prof. of Biochemistry and Symposium Chairman, Euro Business Center, P.O. Box 10552, 1001 EN Amsterdam, The Netherlands

Aug. 31-Sept 4. Cold Spring Harbor Laboratory Conference on Intermediates in Genetic Recombination. Cold Spring Harbor, NY. Info: See for Aug. 24-28.

\section{covins}

Iuly 7. Seminar on Biotechnology Information. London. Info: Marketing and Public Relations, British Library, Science Reference and Information Service, 25 Southampton Blds., London WC2A 1AW, U.K.
July 11-14. Animal Cell Reactor Engineering. Lausanne, Switzerland. Info: Jan Becker, Univ. of Minnesota, Dept. of Professional Development, Continuing Edu cation and Extension, 315 Pillsbury Drive S.E., Minneapolis, MN 55455

July 15-31. Carolina Workshop on General DNA Technology: Cloning cDNA into Expression Vectors. Chapel Hill, NC, Info: Susan J. Kelly, Workshop Coordinator, University of North Carolina at Chapel Hill, Program in Molecular Biology \& Biotechnology, 402 Swing Bldg. $217 \mathrm{H}$ Chapel Hill, NG: 27514

July 18-27. Modeling, Simulation, and Optimization of Chemical Processes. Cambridge, MA. Info: Director of the Summer Session, M.I.T., Room E19-356, Cambridge, MA 02139

July 25-Aug. 5. Molecular Biology of Prokaryotic Differentiation. Oeiras Codex. Portugal. Info: N. van Uden, Gulbenkian Institute of Science, 2781 Oeiras Codex, Portugal

Aug. 7-12. Progress in Recombinant DNA Technology and Applications. St. Charles, MO. Info: Washington Univ. Biotechnology Course, Campus Box 1198, St. Louis, MO 63130

Aug. 29-31. NATO/FEBS Advanced Re search Workshop on Evolutionary Tinkering in Gene Expression. Spetsai, Greece. Info: M. Grunbery-Manago, Institut de Biologie Physico-Chimique, 13 rue Pierre et Marie Curie, 75005 Paris, France

\section{ECUIJE CHNic:}

The Recombinant DNA Advisory Committee (RAC) of the National Institutes of Health (Bethesda, MD) appointed Gerard J. McGarrity chairman through July of 1991. He is president of the Coriell Institute for Medical Research (Camden, NJ).

Viagene (San Diego, CA), a specialist in gene delivery technology, named Douglas J. Jolly director of research.

Gelman Sciences (Ann Arbor, MI) promoted William C. Emhiser to president.

Alfred Benzon Inc. (Philadelphia, PA), a subsidiary of Benzon Pharma A/S (Copenhagen), appointed James W. Sharpe director of business development for Benzon Biosystems. He had been international manager of marketing and sales for in vitro diagnostics at Centocor (Malvern, PA).

Finnigan MAT (San Jose, CA) established a new analytical biochemistry group to be headed by Ian Jardine.

Hana Biologics (Alameda, CA) named Dennis B. Costello vice president of sales and marketing. 